\title{
The Impact of Culture on Performance Appraisal Reforms in Africa: The Case of Uganda's Civil Service
}

\author{
Gerald Kagambirwe Karyeija, PhD (Bergen) \\ Lecturer in Public Administration and Management \\ \& Course Manager Masters in Public Administration \\ Higher Degrees Department, Uganda Management Institute \\ P. O. Box 20131, Kampala, Uganda
}

Tel: 256-702-432-884, 256-782-717-695Ｅ-mail: Gerald.Karyeija@gmail.com

Received: September 29, 2011

Accepted: November 17, $2011 \quad$ Published: April 1, 2012

doi:10.5539/ass.v8n4p159

URL: http://dx.doi.org/10.5539/ass.v8n4p159

\begin{abstract}
This article explores the impact of administrative culture on performance appraisal reforms in Uganda's civil service. Data gathered from 147 questionnaires, 29 interviews and various documents indicates that administrative culture sabotages the actual conduct of performance appraisals and undermines its institutionalization. The study supports the use of power distance and uncertainty avoidance. The additional dimensions of political (neutrality) biasness and ethnicity are a highly relevant addition to the literature on administrative culture and its linkage to instruments of management. Thus, for the successful introduction of performance appraisals, culture matters because the performance appraisal is imposed from abroad and requires a compatible host administrative culture in order to take root. In this case, the host administrative culture was not compatible in many respects with the values underlying the appraisal reforms. Although the Ugandan government introduced appraisal reforms, incompatibility between the values embedded in the appraisal and the host administrative culture watered down the reform.
\end{abstract}

Keywords: Performance appraisal, Reforms, Administrative culture, Uganda, Values

\section{Introduction}

Performance appraisals provide the basis for making selection and promotion decisions, determining salary increases, and they are a vehicle for feedback between supervisors and employees. Although a few studies concerning performance appraisals and culture have been published (György, 2004; McCourt \& Foon, 2007), research on culture and performance appraisals is generally thin and more studies are required in order to understand them (Murphy \& Cleveland, 1995). For the successful introduction of performance appraisals, culture matters. This is because institutions or systems imposed from the centre or abroad - even democratic ones - do not take root by themselves. They need soil in which to grow. Cultural values and norms that are compatible with performance appraisal may suggest the sort of soil that is needed (Baldersheim, et al., 2001, p.52). This article analyses the relationship between administrative culture and the introduction of performance appraisal reforms in the Ugandan civil service. It explores the extent to which performance appraisal reforms are introduced and institutionalized in terms of their acceptance by the civil service; an area which has received little attention from researchers. The purpose of the paper therefore is to propose that it is critical to recognize administrative culture in the developing world, before administrative reforms, like performance appraisals can be considered. It seeks to answer the question: Is the administrative culture of Uganda's civil service receptive or resistant to the NPM inspired performance appraisal, and how? Who in the bureaucracy is more resistant to appraisal reforms, and why?

\subsection{The performance appraisal system in Uganda}

The performance appraisal - an instrument used by organizations to evaluate the performance of their employees in terms of quality, quantity, cost and time - is said to be one of the most problematic components of human resource management and is at times viewed as a futile bureaucratic exercise (Coutts \& Schneider, 2004.), yet it plays an important role in providing the basis for making selection decisions, determining salary increases, and 
providing feedback between supervisors and employees (Mount, 1984,p.1). For the period 1976-1997, the Ugandan civil service used the annual confidential report which was a closed system of assessing individual performance. The appraised individual never received feedback on how he or she faired in the appraisal. The appraisal was confidential thus open to abuse and susceptible to favouritism, corruption and tribalism. Reforming the appraisal was in a way learning of best practices from elsewhere. The second period - the main focus of this article - stretches from 1998 to August 2008, and concerns a 'new' performance appraisal system introduced to the Uganda civil service. This appraisal was considered superior because it; included assessment of critical competencies needed to achieve outputs, provided for an appraisal meeting, allows appeal, open/interactive, and had provision for developing concrete action plans to improve performance and staff development. Thereafter, in 2009, another performance appraisal took effect, and it may be too early to judge its performance.

\subsubsection{Why the performance appraisal reform?}

Following recommendations from the Public Service Review and Reorganization Commission (PSRRC), Uganda introduced a new performance appraisal as part of its administrative reform efforts to improve the public sector performance. The PSRRC noted that civil servants needed to be objectively assessed on their actual performance in relation to well defined targets and tasks agreed upon between themselves and their supervisors. However, this new 'open' appraisal system also turned out a failure for the following eight reasons:

1) According to the Implementation Evaluation Report of 2005/6, the success rate was at $30 \%$. This means that appraisal forms were sometimes not filled out; the forms were sometimes not available, and when provided were photocopies; appraisals were not conducted at appointed times; employees who were supposed to conduct self-appraisals were denied that opportunity; performance targets were either dictated by the superior or expected by the junior and not jointly agreed upon; no feed back; sometimes there was too limited knowledge about the appraisals.

2) The head of the civil service acknowledges that performance appraisal was a failure since it lacked responsiveness from the civil servants (Mitala, 2006).

3) The idea of replacing performance appraisal implies that it was unable to meet the desired expectations. Moreover, there was no indication that after implementing the appraisal for five years, it would be replaced.

4) Quite often, civil servants did not prepare annual performance plans for individual staff, but this was supposed to be the basis for conducting appraisals (Tidemand and Ssewankambo, 2008).

5) Results of the performance appraisal exercise were not immediately analyzed and used to inform individual goals (Tidemand and Ssewankambo, 2008).

6) According to interviews collected for this study, performance appraisals were mainly conducted when civil servants were expected to be confirmed or promoted.

7) The appraisal instrument was never used for sake of reward and recognition (Tidemand and Ssewankambo, 2008).

5) There was 'limited implementation of the appraisal' in local governments (MOPS, 2007).

\subsubsection{Performance appraisal and culture}

Every country in the world has a need for performance appraisal and actually carries out these reforms; however, I contend that their success depends on the context. Despite several efforts to reform public service organizations in developing countries, tangible improvements are few and far between (Polidano, 1999; Schick, 1998). One cannot undermine the ability of cultural variables because 'Social arguments tied to organizational culture can potentially have an instrumental side, that is, informal norms and values can be useful. Employees can feel more loyal and function better because the institutional aspects of their activity are emphasized' (Christensen, et al., 2007, p.39). One must not simply blame and criticize public servants, but seek their views and experiences on why appraisal reforms are accepted or rejected, why they fail or succeed. Civil servants may work against a reform without knowing that they are doing so. This is because they have been socialized into particular ways of doing things and may not realize or appreciate other ways of doing things. After all, 'when they [the civil servants] have relied on foreign experts, the outsiders have too often ignored domestic circumstances and confused matters by incorporating their foreign values' (Caiden, 2006). Thus, it is pertinent to investigate how administrative culture affects performance appraisal. 


\section{Administrative culture}

Many definitions of administrative culture pertain, and I will cite a few for elaboration: It is 'the general characteristics of public officials, i.e., shared values, attitudes and beliefs' (Henderson, 2005, p.41). Zhuplev and Shein (2005, p.109), believe administrative culture manifests itself in behavioural norms, adopted and adhered to by participants of the governance process. James Wilson (1989, p.110) defines it as a persistent way of thinking about the central tasks of an organization and the human relationships within it. Anechiarico explains it as a transmissible pattern of beliefs, values and behaviour in a public service organization that concern the organization's role and relationship to the public (cited in Luvuno 2005, p.210). It has also been described as the interpretative profile of the significant underlying structure, which includes practices, shared views, and value systems amongst functionaries; it is embedded in the way societies address and interpret their problems and includes the collective reflection and sharing of historical memories, myths and symbols, as well as past cleavages (Nef, 2005,p.232). In this article, administrative culture is the shared values, beliefs, norms, traditions and practices of public officials.

\section{Measuring administrative culture: The dimensions}

The dimensions of administrative culture used in this article are based on known variables used to measure and describe culture - namely, power distance, uncertainty avoidance, political neutrality/bias, and ethnicity. Although some of these variables are commonly used for cross national studies, they are mirrored in the bureaucracy because organizational culture is isomorphic to societal culture (György, 2004, p.37; Hofstede, 2001; Jahoda, 1984; Javidan, et al., 2004). It is for three reasons, that I choose these variables. First, several studies have used these variables, and researchers have proposed that managerial practices can be predicted by various national values (Aycan, 2005; György, 2004; Hofstede, 2001; Hofstede \& Hofstede, 2005). Therefore I use these studies as a point of departure for my study. Second, the variables are mirrored in the civil service (House, et al., 2004; Peters, 2001; Islam, 2004, 2005) hence it is relevant to use them as a point of departure in analyzing the administrative culture of Uganda. Third, ethnicity and its consequences have for long been associated with African maladministration and the claim is gaining prominence (Chabal \& Daloz, 1999; Olivier de Sardan, 1999; Hameso, 1997; Nnoli, 1993; Tambiah, 1989). It is therefore important to apply and analyze them with regard to the civil service in Uganda. I now analyze them one by one.

\subsection{Power distance}

Power distance is the extent to which the less powerful members of institutions expect and accept that power is distributed unequally. Hofstede's survey of East Africa considers the region to have a high power distance culture. By inference therefore, we could suppose that Uganda is in the same range. In high power distance cultures salary systems show wide gaps between top and bottom in the organization (Hofstede \& Hofstede 2005, p.55). This has a number of implications to the performance appraisal. With large power distance, the bureaucracy is highly centralized; juniors are not expected to challenge authority openly or to participate in decision making but to take orders (Munene, et al., 2000). Yet, given that the performance appraisal is expected to be participatory, then it may not succeed well in a hierarchical environment characterized by large power distance. According to Mendonca and Kanungo (1994), all the critical activities in performance appraisal require the manager to function as a coach and mentor to his subordinates, but high power distance undermines mentorship and promotes sycophancy. There is also the appraisal feedback process, to which Fletcher and Perry (2001) observe that employee appraisals and feedback on results in large power distance organizations will most often be conducted by a person with relatively more power than the ratee, while in low power distance cultures performance appraisals are less dependant on superiors.

Power distance could also be perceived in the form of the colonial chief factor (Note 1). The chief signified total, absolute power, unchecked and unrestrained (Mamdani, 1996). This legacy has lived to date. No wonder the success rate of the annual confidential report in Uganda's bureaucracy was high (Turya-Muhika, 1982), but when this was replaced with the more transparent performance appraisal, the success rate declined. One of the possible reasons is because the old annual confidential report preserved the power of the rater and hence was 'fitting' for a high power distance culture. This manifestation of power distance is re-enforced by status symbolism, whereby privileges and status symbols contribute to the authority of the bosses. In a large power distance culture, those in power would like to see the performance appraisal as another symbolic exercise that contributes to their authority. Additionally, in order to overcome red tape in bureaucracies, informality (Note 2) comes in and causes civil servants to pay limited attention to performance outputs and results (Schick, 1998). Yet, performance appraisals usually require the assessment of competencies, integrity, initiative and work relations. Therefore, the presence of high power distance in the Ugandan civil service may prevent participatory 
decision making, abate transparency and compromise merit. Hence it may be difficult to introduce performance appraisal.

\subsection{Uncertainty avoidance}

Uncertainty avoidance is the extent to which the members of a culture feel threatened by ambiguous or unknown situations. The concept denotes a deficit in knowledge about what the future may hold, it expresses the extent to which people either tolerate ambiguous situations or need formal rules (Hofstede \& Hofstede, 2005). Uncertainty may be weak or strong. Bureaucracies in strong uncertainty cultures are more likely to create and maintain rules than in weak uncertainty cultures, and people in the strong uncertainty culture will tend to avoid situations that may not be easy to tackle. Hence their leaders may create more rules and regulations to ensure control. With regard to rule-following, civil servants who are subjected to rigid and complex rules seldom take initiative (Jabbra and Jabbra, 2005). Other than the issue of rule following, Mendonca \& Kanungo (1999) argue that the relatively high uncertainty avoidance in the developing countries implies that civil servants are unwilling to innovate and are risk averse. When performance appraisal is introduced in the high uncertainty avoidance culture, civil servants may resist appraisal reforms because they have to learn something new.

Since one of the critical purposes of the appraisal is that it be used as a basis for rewards and sanctions of some sort, it is important to understand the impact uncertainty avoidance has upon the appraisal. Various studies have found out that countries with weak uncertainty avoidance show that bonuses should be linked to performance, whereas countries with strong uncertainty avoidance are less likely to use the variable of performance bonuses because they create more ambiguity than the executives are willing to accept (Mcfarlin \& Sweeney, 2001, p.75).

The level of control over environment vs. feedback management: becomes important when reviewing past performance. Munene, et al., (2000) argue that Ugandans view themselves as having complete control over their environment. Uncertainty avoidance in India evidenced through karma (inevitable fate) has been used as a rationalization for accepting sub-standard performance of the appraisal (Groeschl, 2003, p.72) because supervisors do not give feedback, or the feedback is rationalized in such a way that makes it inoperative. It is thus supposed that the higher the degree of uncertainty avoidance, the more the risk aversion and rule following, the less the innovation and the more the concern for maintaining the status quo. Such a situation may impede the introduction of performance appraisal in the Ugandan civil service.

\subsection{Political neutrality vs. political bias}

Political neutrality denotes civil servants performing their jobs professionally and without biases towards politicians. On the other hand, political bias connotes a partisan bureaucracy that is more loyal to the interests and preferences of the ruling party. According to Putnam (1975), attitudes of bureaucrats may be classified into classical and political. A classical bureaucrat is more procedure-and rule oriented while the political bureaucrat is more problem-or program oriented. A classical bureaucrat may dislike political influence and intervention by political leaders in the daily affairs of the bureaucracy. They are likely to be more distrustful to politicians. In contrast, a political bureaucrat is more sensitive to political signals and trusts politicians. If a bureaucracy is more classical, their dispositions to appraisal reform measures by the government may vary from being positive to negative. To secure positive responses, their cooperation needs to be nurtured by involving them in implementation. In contrast, politically biased bureaucrat's inclination is to support government policies. Their positive disposition is taken for granted.

The bureaucracy in Bangladesh is influenced more by the British colonial administrative norms and hence bureaucrats there display more classical norms (Jamil, 1998, p.97). Similar to Bangladesh, we may also expect the Ugandan bureaucracy to be classical, since Uganda was also a British colony. In the case of Uganda, bureaucrats are more classical because they are selected and promoted on the basis of merit. However, in recent years we observe politicization of the bureaucracy and administrative reforms are accepted primarily for political survival (Mwenda \& Tangri, 2005). If selection of key positions in bureaucracy is based on political patronage, bureaucrats may change from being classical to political bureaucrats. This in turn would make them more loyal and supportive to the performance appraisal system. It is thus reasonable to suggest that the higher the degree of political biasness in the Ugandan civil service, the more the loyalty, patronage and trust of politicians, and hence the more likely the introduction of the performance appraisal reforms.

\subsection{Ethnicity (Note 3)}

Ethnicity is a very contentious issue in discussions on culture and political theory. Ethnicity could be seen as a characteristic of collectivist cultures whereby people, from birth onwards, are integrated into strong, cohesive in-groups; the group that person is in continues to give protection in exchange for unquestioning loyalty 
(Hofstede \& Hofstede, 2005). Ethnicity is an aspect of social relationships between agents who consider themselves as culturally distinctive from members of other groups with whom they have minimum regular interaction (Eriksen, 2002, p.13). Ethnicity is a social construction, a factor in the dialectics of domination and emancipation. Ethnic affiliation provides a sense of security, a source of trust, certainty, reciprocal help and protection against the neglect of one's interests by strangers (Horowitrz, 1994, p.49) especially in situations of alienation, and insecurity' (Lentz, 1995).

In Uganda, like most of Africa, people do not strive to make autonomous choices. They take into consideration the consequences of their choices to other people (Hyden, 2006, p.191). It has been observed that the objective of ethnicity is to obtain and use state power, in order to gain access to resources commanded by the state or defend ethnic identities from state intrusions (Okuku, 2002, p.9; Hameso, 1997). The debate on ethnicity in the appointments of public officials in Uganda presents two issues; one is on representation, the other on professionalism (Mwenda, 2008). In such a scenario it would be expecting way too much to anticipate that merit-based promotions will happen - in effect, the performance appraisal is rendered irrelevant. Even leading academics accuse each other of practicing tribalism at work (Kagolo, 2008). The most important point here is that certain tribes are accused of monopolizing high offices. It is easy to want to agree with those who argue that ethnicity is the cause of the country's problems. Whether Uganda is ethnically challenged or not is yet to be confirmed, but what is clear is that the concern is more prominent than ever before and cannot be wished away or ignored any longer. More importantly, this concern - as well as values and perceptions which are related to it in society - is partly responsible for shaping the administrative culture of the Ugandan civil servants. 'Manyi ani' ('whom do I know') and 'Mwana waani' ('whose child') are two ethnically based social formations dominating the Ugandan scene, and have been institutionalized to the point that they sometimes influence the way formal institutions operate. In fact, one of the ways they manifest themselves is in the recruitment of certain personnel. In Uganda there is a saying that 'technical know who is better than technical knowhow', meaning that in order to get a job or a promotion, who one knows matters more than what one knows.

Research on performance appraisal has revealed that ethnic and race-related bias plays a role in the implementation of performance appraisals. Kraiger \& Ford (1985), concluded that the ethnicity of the ratee has a significant impact on performance ratings in the United States. White raters tend to evaluate fellow whites 64 percent higher than for a black ratee, and the black rater evaluated the average fellow black 67 percent higher than a white ratee. In another study in the United States, it was also observed that white bosses assigned more favourable ratings to ratees of their own race (Mount, et al., 2006). Yet despite the cited studies which find race or ethnicity to be highly significant in the workplace, other studies have found such variance small (Brooks \& Clunis, 2007). From these findings we could extrapolate that in a multi-ethnic bureaucracy like that of Uganda, ethnic bias in the performance appraisal is highly likely as well. Supervisors may give favourable appraisals to those of their own ethnic background. The more the interpersonal relationships in the civil service are influenced by ethnicity, the more it may compromise neutrality, impartiality and merit, and hence the less likely the success of the performance appraisal in the Ugandan civil service.

\section{Administrative culture in Uganda's civil service}

This study notes that cultural values are numerous, flexible, hidden, changing, intersecting, dynamic and resilient. Therefore the ones used in this study are only indicative and not exhaustive. Moreover, they may also be helpful in explaining certain loose ends and peripheral aspects of administrative culture. In a recent study, Karyeija (2010) found that large power distance, high uncertainty avoidance, political neutrality and ethnicity characterize Uganda's administrative culture.

On a scale ranging from 1 to 5 , whereby 1 represents the least prevalence of the variable and 5 the highest, an index which revealed the following results based on the mean was developed: power distance 3.7, uncertainty avoidance 3.8 , high political neutrality 3.9 , and ethnicity 3.5 , as reported in tale 1 above. All the four variables scored above the median (i.e., 3) and thus one may conclude that the Ugandan bureaucracy is characterized by a high presence of Large power distance was evidenced by a steep hierarchy, a wide range of salaries, the colonial chief mentality, disparities in status and a focus on status symbols, Strong uncertainty avoidance was mainly suggested by rule following, risk aversion and lack of innovation, and High political neutrality where bureaucrats prefer to be neutral and independent of the politicians, but at the same time politicians, and deride the politicization of the civil service. With regard to ethnicity, findings revealed that there is ethnically based favouritism. 


\section{The Impact of culture on performance appraisal reforms in Uganda's civil service}

In this section, I detail how aspects of administrative culture may impede the performance appraisal system in Uganda. I start by looking at the impact of power distance.

\subsection{Large power distance and the performance appraisal}

\subsubsection{Hierarchy}

Hierarchy is a major component of large power distance. Those who value hierarchies tend to expect juniors to express deep loyalty, and this tendency has serious implications for the performance appraisal system. For instance, members of the low cadre civil service note in interviews that while they are carrying out their jobs, what matters is to fulfil the boss's personal preferences, as an individual, and not in his/her official capacity. As such, the ultimate grading in the performance appraisal system does not measure what the individual staff member has done for the organization, so the appraisal actually becomes redundant and useless. Secondly, there is the problem of bosses imposing goals upon their staff rather than the staff participating in devising what those goals should be. It is expected that the rater and the ratee sit down and agree on targets, but this seems not to be what is practiced. If the performance appraisal system is to be implemented as prescribed in the guidelines, then it ought to be fair, transparent, objective and participatory. However, adherence to these principles would disturb and undermine the existing power structure, interpersonal relations and hierarchy.

\subsubsection{Feedback management and appraisal environment}

Feedback management is very important in the conduct of performance appraisal. The rater is responsible to ensure that feedback is given to the ratee. Feedback during performance appraisal reviews in Europe tends to allow the ratee to express dissent. Such behaviour is not considered appropriate to employees in Uganda, for face-saving is regarded as more important than learning from the appraisal review. People are not socialized to interject their ideas in an appraisal review and to explain and defend their point of view. In addition, they are mostly oriented towards showing the supervisor respect. One way of expressing respect is to avoid presenting potentially contradictory views. Respondents indicate that there is a high propensity for the 'command and control' method of directing activities, yet the performance appraisal system promotes the view that people should discuss the variables upon which their success will be measured.

In addition to the problem of feedback, the environment in which the performance appraisal exercise is conducted also emphasizes power distance and therefore undermines the intention of the appraisal meeting. The study found that most appraisal meetings take place in the raters' office and the rater may allow interruptions, taking phone calls and attending to other people. Thus the environment in which the appraisal unfolds undermines the appraisal's objectives and proves only to underscore power distance. The minimal feedback and interaction on goals and objectives, and the reticence to express contrary views all lead to the exercise not being respected; it becomes a distasteful ritual, something only to be endured.

\subsubsection{Power distance in terms of gender and generational differences}

Large power distance partly arises from some people being awarded a culturally superior status, e.g., elders, men, bosses and anyone in authority. The inequality of persons, not least gender and generation differences, causes the appropriateness of the performance appraisal system to come into question because the latter is predicated upon supervisors and subordinates negotiating the subordinate's annual objectives. This is difficult because of the high degree of power distance between bosses and subordinates. The difficulty also extends to gender and generation differences. In terms of gender, we observe that there is always tension when a supervisor is a woman and she must negotiate objectives with men, worse still, and older men. In such cases it is common to find that the rater's decisions are not based on facts but on opinion. Young senior bosses tend to negotiate objectives with their older subordinates. Due to the cultural constraint that elders must be respected, the possibility of having the appraisal favour elders and other culturally superior persons is high. Consequently the spirit of the performance appraisal system is undermined.

\subsubsection{The attitude of the chief}

If a boss assumes himself to be 'the chief', he assumes that every element of power is in his hands. First of all, the rater and the ratee may avoid instances where self-esteem can be hurt. Secondly, since the appraisal exercise is not yet seen as a tool for wielding power, assessors do not feel a sense of pride and power when using it. Indications from the study suggest the unlikelihood that subordinates would question managerial intentions, especially if the supervisor considers himself a 'chief'. Therefore, as long as those in authority think that the performance appraisal does not give them the ability to dole out rewards and sanctions, they will either not carry out the appraisal or simply fill it out in a perfunctory manner. Meanwhile, salary increments are actually based 
on the following: a) re-grading jobs, b) joining the senior levels of technical and professional jobs, c) pay awards to select groups of public officers due to the pressure exerted on the political leadership, d) legal provisions for some government agencies to determine their salaries, and e) working on donor-funded projects. Due to the 'chief' factor, civil servants are more likely to accept the appraisal if it is imposed by superiors through top-down decision making. This is because they want to show how well behaved they are in order to be rewarded. They also know that the rater may easily use the appraisal report as a basis of re-grading ones job or select the favourite to work on donor funded projects, which in turn may lead to salary increments.

\subsubsection{Privileges and status symbols and their effect on performance appraisal}

There is always immense pressure from society to know how far one has climbed the leadership ladder, and the belief that one's rank in the hierarchy reflects differences in quality stimulates the need and desire to be promoted. Given that the performance appraisal system is not directly tied to the promotion system, it is seen as a waste of time. Juniors treat the filling out of appraisal forms as a routine and the seniors sign them as a duty. But this should not suggest that it is a totally misplaced document; it can occasionally be used to justify decisions. What is clear though is that there is lack of enthusiasm concerning the performance appraisal form, and the whole system seems irrelevant. According to this study's respondents, it appears that the performance appraisal system disrupts the existing power structure by requiring self-assessment by the appraised. Having to share evaluative power - this is a power all parties see as a privilege of the rater - may also invite resistance from the ratees. In the first instance, power has been shared, and the superior who views himself as a benevolent benefactor is now 'reduced' to a mere partaker in the decision making processes. Evidence from the interviews supports the conclusion that self assessment and agreement between the rater and ratee on a joint action plan is considered inconsistent with the 'natural flow of power', as one respondent put it. Most disturbing: the rater must hand over the appraisal form to a countersigning officer to confirm that the assessment is done correctly and is genuine. By making this demand, the appraisal is perceived as a tool that undermines the power, influence, status and privilege of the 'chief'. Consequently it is given less attention and priority, less commitment, it is not conducted in a timely manner, and feedback is haphazard. In this way, the appraisal reforms are slowed down and the intentions of the reformers are not met.

\subsection{Strong uncertainty avoidance and performance appraisal reforms}

\subsubsection{The paradox of rule following}

It may seem paradoxical that civil servants who feel comfortable being rule followers feel uncomfortable with the appraisal which is also a set of rules. One possible explanation for the paradox in rule following is that when rules tend to disfavour employees and cause them to feel uncertain, the employees try to circumvent them. In this case, the rater feels in charge of the future by determining the performance targets - a solution far easier than having to agree on targets with the ratee, yet it undermines the principal of having both parties agree on the performance targets. Another reason for the paradox in rule following is that since respect and promotion are results of seniority, the performance appraisal system may be undermined because of the general attitude towards young people. Ugandan bureaucrats have a strong desire to hold onto their jobs until retirement, given that the nature of civil service provides job security and thus is a way to overcome uncertainty. Because of this, even though they do not like the performance appraisal, they will fill out the form yet be delinquent in doing so. Although there are so many rules and regulations guiding the usage of performance appraisal, they are not respected as they ought to be. In fact, civil servants try their level best to circumvent them to suit their interest. This is contrary to reformers' expectations, for if the civil servants are truly a rule following lot, then they should be experiencing a perfect appraisal system.

\subsubsection{The effect of 'psychological contract' on performance appraisal}

In societies with high uncertainty avoidance cultures, there is a unique type of 'psychological contract' whereby the boss and the subordinate tend to back up each other even if the performance of the junior is poor (Schein, 1999). There is a need for interdependence that is mutually beneficial. One respondent had this to say: 'I know my permanent secretary is very busy. When the time for them comes like for promotion, I will fill them out and take them to him for signing. He is not bothered about those so-called indicators.'

The sentiments contained in this quote are echoed by most respondents; we descry a 'contract' between the rater and the ratee to do what works for them regardless of what the rules say. The intention of the 'contract' is to forestall uncertainty. Doing so is a clear indication that they are not committed to seeing the performance appraisal succeed. At the same time, the 'psychological contract' practice is more than just an affront to objectivity because the appraisal has not been filled out at the stipulated time. All this contributes to sabotaging the appraisal at the implementation phase. 


\subsubsection{Uncertainty and performance targets}

Within the context of high uncertainty avoidance, there is a strong need for precision. However, some of the work in the civil service is difficult to quantify. For instance, it's difficult to do a joint appraisal on the basis of agreed indicators when the standing orders explicitly give heads of department control over a subordinates' schedule through a clause stating that the junior will handle '....any other tasks that may be assigned by the superiors'. It is also possible that a subordinate could be required to do work outside his job description, and then it becomes practically impossible to appraise the person on such tasks. This renders the tool itself inconsistent with the administrative culture, and thus constrains its actual design and implementation. But it becomes difficult to apply the appraisal instrument in an organization where work is sometimes ad hoc and where some of the output is qualitative in nature. Thus in the long run, unless this mismatch is managed the performance appraisal cannot take root.

\subsubsection{Ambiguity in relation to performance appraisal}

Ambiguity in the performance appraisal thwarts innovation, which is intended to be one of the main purposes of the appraisal exercise. Much as there are guidelines and workshops, measuring qualitative work quantitatively requires a high level of specificity in a strong uncertainty context like Uganda. Take for example the qualitative variables specified under 'Part C' of the appraisal form: Professional knowledge, Planning, Organizing, Leadership, Decision making, Management of resources, and Loyalty; these are not clearly denoted with marks. The potential conflict of interest leading to ambiguity which the interviewees mention concerns celebrations like marriages, baptisms and funerals. Many civil servants consider these very important. The appraisal form and process does not recognize and adequately accommodate for the importance of these celebrations, and the bureaucracy assumes that contemporary official behaviour should not be bound by such traditions. One respondent wonders why she cannot be excused for having failed to accomplish a task because she took leave for 'more days than enough' to attend a relative's funeral. She insists that in such a situation her performance would be negatively impacted since her perception is that civil service management practices do not take into consideration her cultural values. Some supervisors will go ahead and give her permission to attend the funeral and when the time for assessment comes; they will give a favourable appraisal because they 'understand' the reasons why she could not meet her target. But more remarkable than this example is the ambiguity-generating practice of double standards: those who deny or pretend to deny permission for such celebrations are themselves the most culpable, for when they themselves are involved in such celebrations they are known to spend more time and even government resources on them. Yet their subordinates have no opportunity to critique them given the structure of the Ugandan performance appraisal system.

\subsubsection{Innovation in relation to performance appraisal}

Along with the problem of ambiguity we find the problem of innovation. In large uncertainty-avoidance cultures, innovation is less encouraged. Data for this study reveals that innovators within the civil service feel constrained by the rules. Radical ideas are avoided in favour of maintaining the status quo, rendering the appraisal system less effective. This situation is most apparent when the performance appraisal form requires a supervisor to assess the junior's core job competencies, and yet there is no provision for evaluating the level of creativity and innovativeness of the civil servant. If the performance appraisal is designed to improve efficiency and effectiveness, how then can it achieve this goal when it does not allow the ratee to be assessed on innovation? The whole appraisal form is made in such a way that it focuses on technical solutions and behaviour. Juniors are discouraged from enacting innovative behaviours that are not formally part of their job descriptions. Therefore, the appraisal exercise may appear to be working, but the intention is largely unmet - hence a challenge to the appraisal reform.

\subsubsection{Risk aversion and performance appraisal}

The relatively high uncertainty avoidance implies unwillingness to take risks and accept the changes the performance appraisal system would entail if fully implemented. This is manifested in the reluctance by civil servants to take initiatives outside of prescribed roles. This is confirmed by an official who says: 'Within the civil service, we handle things very carefully. Therefore for the performance appraisal to succeed, we have to implement it in bits, but if you want to make people commit themselves to an ambitious programme, they coil. Civil servants are risk averse!' she said.

In the quote above, the lady declares that civil servants are risk averse, which is in agreement with what many other respondents said. I interpret this quote also to mean that civil servants approach appraisal reforms with caution and do not want to embrace it all at ago because they fear that they may fail to implement it well. Therefore they set minimal targets or easy milestones with regard to its implementation which slows down its 
institutionalization. Neither the rater nor the ratee will get involved in setting challenging tasks. In turn, it reduces the possibilities for the performance appraisal to function well.

\subsubsection{Expert power and performance appraisal}

The recognition of the value of expert power is characteristic of Hofstede's uncertainty avoidance dimension (Hofstede \& Hofstede, 2005, p.189). This leads to the proposition that had the performance appraisal form given more prominence and reference to expert power; it would have been more effective. Of the 10 competence areas for evaluation, only one refers to expertise. This also could be interpreted to mean that Ugandan civil servants, being more predisposed towards high uncertainty avoidance, tend to view the results-oriented performance appraisal as a tool that has little impact as far as their career development is concerned. If the appraisal is perceived as an instrument which minimally addresses expertise, then ratees do not consider it useful and will naturally give it less attention in relation to other activities. In addition, the desire for experts to be recognized also undermines the performance appraisal because Ugandans have a strong need to be surrounded by loyal people. This loyalty and respect comes about because the senior is considered an expert in the area and it accentuates his control over juniors. In interviews, respondents agreed that having loyal juniors not only motivates the senior, but is desirable. However, the extent to which this state of affairs enhances a fair, transparent and objective performance appraisal is questionable, given the cases of unfair dismissals, promotions recruitments and frustration. In other words, civil servants who are oriented towards strong uncertainty avoidance may feel uncomfortable in new situations. They are likely to avoid ambiguity and uncertainty as much as possible. Clearly, these civil servants, influenced by perceived uncertainty, will not accept the values of the performance appraisal until after consistent revisions have honed it to fit with the host culture.

\subsection{Political neutrality and performance appraisal reforms}

The political aspects are very important for the success of appraisal reforms. A commonly invoked condition for the successful implementation of administrative reforms is political support from the executive branch of government (Flynn, 2002). President Museveni personally introduced key reform issues to Uganda. He claimed that these reforms were hatched during the five years he was leading a guerrilla war. However, given the prevailing situation concerning political support, we find that the most successful exercise was downsizing of the civil service by about $54 \%$ in five years. Why then is their seemingly little support for the performance appraisal? It is the contention of this study that the performance appraisal has limited support because of high political neutrality amongst the civil servants and because they may also have less support for the incumbent.

\subsubsection{Political will and symbolism}

Some respondents indicate that the performance appraisals, together with other reforms, are intended to give the National Resistance Movement (NRM) government much needed legitimacy. The reforms appear to give an impression that the fundamental change of making the civil service more efficient and effective has been achieved. Sometimes government actions are intended to gain public support. Therefore, a few questions confront us: is the performance appraisal meant to show the public that at last the government is interested in streamlining the civil service? Does the government want to win the support of the public servants, who the president has often referred to as his political enemies? Is it done because the donors will lavish these reforms with much needed money? Is the performance appraisal just another showcase to the multilateral agencies that the country is undergoing transformation? The population is demanding more accountability from the government and one way to show this accountability is to provide a package of administrative reforms within the public service. This package definitely includes performance appraisal. Findings of this research show however that civil servants are seldom fired due to poor performance. In this respect, the introduction of the appraisal system appears to be part of an attempt by the government to gain legitimacy by window dressing itself with the principles of transparency and meritocracy. But due to the political leaders' attitude towards the civil service they believe it is full of opposition members - one could argue that the aim of portraying the government in good light through the introduction of the appraisal system is a mere symbolic act rather than a true attempt to make the public service better. To achieve legitimacy through the appraisal, the state must build strategic relationships with the civil servants.

Yet another political issue is the source of the reforms: most respondents of this research share the view that with limited faith in government policies, it can be difficult to implement the appraisal system. With the government taking a cautionary approach, it is understandable that no reward has been linked to the appraisal. Meanwhile, the lack of any punishment for not implementing the system adequately has created a sense of low priority and less attention being given to implementing the appraisal system. Although most interviewees disfavour coercive 
measures, they highlight the lack of attention the appraisal receives and the absence of political will to make government implement it. Does the government have the will to enforce compliance?

It seems civil servants do not want politicians to interfere with the reform processes, though at the same time they consider it an advantage for top civil servants to share political views of the ruling regime. So in such an environment, why do performance appraisals fail? Possibly civil servants may sabotage the process in order to fail the top civil servants and therefore give themselves opportunity to rise in the hierarchy. Another possibility is that it is a passive protest to government. My findings show that bureaucrats want to keep aloof from the politicians; they dislike political interference and therefore resist the performance appraisal because it is perceived as a tool of the NRM. This resistance manifests itself in various ways; the performance appraisal is not conducted. Even when the appraisal is conducted, it is not done on time. In relation to other activities, the performance appraisal is given minimal attention, which shows that there is no commitment to the appraisal system. Yet, in order for the appraisal to take root, it needs commitment and not sabotage. Eventually the resistance and sabotage make appraisal system stale in its progression and institutionalization.

\subsubsection{Attitude of the politicians towards civil servants}

Public servants claim they have suffered and the politicians, led by the President, have accentuated political neutrality, and at times bred some form of opposition. As noted by Polidano $(1999$, p.12), the introduction of modern performance-oriented staff appraisal is a straightforward exercise, but the difficulty comes afterwards because governments are reluctant to link appraisals to career rewards and sanctions. Promotions continue to be based on seniority and at times patronage inter alia. Uganda has made bold steps in applying this model of appraisal, but it falls short because the reform turns out to be long on rhetoric and short on results. Progress on the performance appraisal has been limited and has not been fully internalized. Findings indicate that the momentum is slowing and ministries argue that this is because the performance appraisal was not closely linked to Output Based Budgeting.

Like any other reform and organization process, there is always the issue of internal politics in the ministries that also affects full implementation of the performance appraisal. First, the reform agents prefer to use a technical framework only (e.g. the focus on goals and the availability of enough appraisal forms at hand) for implementing the performance appraisal, rather than a political one. Yet administrative reform is a political process. Decisions taken by certain bureaucrats result in the redistribution of rights, benefits, power and resources, and the existing power holders cannot be expected to surrender power or advantage voluntarily. The second aspect of internal politics relates to involvement. Though the enthusiasm for the performance appraisal has slowed down, it was initially because the civil servants are much keener to implement ideas that are products of their own involvement.

Data denotes that in order for the performance appraisal to succeed it must have the support and approval of politicians as well. Therefore, it is incumbent upon bureaucrats to design appraisal reforms that appeal to politicians; they should be perceived to lend legitimacy or at least appear to respond to public demands. Yet sometimes a gap looms between political priorities and bureaucratic priorities which do not support appraisal reforms. One way to reduce this gap is for the civil servants to develop systems and mechanisms of translating political agendas into implementable policies. But the politicians, who are the supervisors of the ministries, seem not to pay much attention to how successful the performance appraisal reform has been anyway. Perhaps this is because the impact of the performance appraisal is more implicit than explicit and the politicians may be more interested in reforms that yield immediate results. Unless the President intervenes in some aspects, a question arises whether appraisal reforms can be given financial priority. This sort of dependence on the goodwill of the president for the civil service to get sufficient funding has been problematic because the performance appraisal is not politically significant compared to other reforms.

\subsubsection{Patronage}

There have been several complaints that top public sector positions, especially in the important government ministries like defence, have been filled by politically loyal officials. Some of the civil servants view patronage as an unintended consequence of their extreme political neutrality which is perceived as opposition by the ruling government. Therefore because the civil servants are not politically biased and overwhelmingly loyal to the ruling regime, the ruling political elite has opted for patronage to neutralize them. This has undermined the importance of the performance appraisal system which should ideally lead to promotions. The president appoints the Permanent Secretary and therefore those who aspire for the top post would rather play politics. It is self-defeating because the appraisal system could have helped correct institutional distortions caused by the 
political breakdown during the 1970s and 1980s. Instead, patronage is on the rise. The performance appraisal becomes ineffective since employees see it not as an instrument to promote merit, but party loyalty.

This study found interesting views concerning the tolerance of patronage. At least 20 interviews $(74 \%)$ indicate that political connections are responsible for some promotions and recruitment in the public service. A personnel official notes that patrimonial pressure abounds everywhere and is most pronounced at the district level. One of the explanations is based on the premise that the District Service Commission is established by the local politicians and hence is often under pressure to recruit favoured candidates. The political-administrative interface at the local level is full of tension, which inevitably affects the appraisals. According to Kiyaga Nsubuga, 'Numerous efforts have been made to resolve this, including review of the Local Governments Act, 1997, and regular issuance of guidelines by various government bodies, but the problem still persists' (Kiyaga-Nsubuga, 2004), even to date.

One may well ask: if the performance appraisal is not related to promotion, then does it matter if people are recruited on the basis of patronage? This is the dilemma. First, it brings up the problem of double standards: one group of civil servants is promoted on the basis of the performance appraisal and another group is promoted on the basis of political patronage. The issues that come into play therefore are fairness and standardization. The performance appraisal system can take root only if the same rules apply equally to those concerned. Second, there is the issue of presidential appointments which are political in nature; for instance, in the Ugandan civil service, all appointments from Assistant Commissioner to Permanent Secretary are presidential appointments. This means applicants for such positions are interviewed by the public service commission and forwarded to the president for appointment. However, if for any reason, the president is not comfortable with an appointee, he will not appoint the person. In addition, the president also has the discretion to himself appoint individuals and recommend them to the public service for formality purposes. Therefore, if these appointments are political, then promotions based on the appraisal will not be the norm and hence the appraisal system becomes less useful as one moves high up the ladder of hierarchy. For this reason a senior civil servant may find it more beneficial to play politics than pay much attention to a result-oriented appraisal.

In relation to our study, this is a very telling finding: how can a merit-based performance appraisal system thrive in an environment riddled with patronage practices? It would definitely face a lot of difficulty. Objectivity and transparency, which are hallmarks of the appraisal system, are compromised. Civil servants' commitment to it is also undermined since they treat it as having little value. Hence the appraisal system cannot be fully introduced.

\subsubsection{Patronage and performance appraisal}

Most respondents managing the reform process observed that administrative reforms (of which the appraisal is a small component) are dominated by monetary enticements; it was reported that because top civil servants have to meet their donors fortnightly, they have to come up with a shopping list that suits the donor's best interests. Civil servants will allow certain appraisal processes to take place because they profit financially or otherwise from them. Huge donor funds, international pressure and various other avenues may be exploited by corrupt local and international officials. A civil servant asks (rhetorically): 'These civil service reforms come with money, vehicles, computers, etc. Why then reject them?' This is a tempting situation, given the culture prevalent in the bureaucracy. The merits of the performance appraisal are inconsequential as long as the bureaucrats can profiteer by accepting these reforms from the donor community. In a study including Uganda, it has been reported that civil service officials negotiate with donors over the design of projects, but the officials' main concern is their own personal financial benefit. This leads to distortion of donor interventions - pointless study tours, use of local consultants, vehicles, cellular phones and so forth (Wescott, 1999, p.28). Other findings indicate that during the initial stages of the performance appraisal, the idea of participating in a big reform programme is welcomed. It created opportunities for certain civil servants in the form of salaries, allowances, official cars, and domestic or foreign trips. This is because usually, the key personnel involved in conceiving and initiating a particular reform are the ones who end up implementing it (Mwenda, 2007, pp.30 -31). With time, however, enthusiasm towards the appraisal fades because it is no longer capable of providing these prerequisites. The interviews indicate that civil servants will prefer to give attention to issues where they can earn extra money from the donors, but the performance appraisal seems not to be in that category. I could as well conclude that the performance appraisal was formally given by the donors, formally adopted by the civil servants, but informally and in practice, the civil servants have evaded it because of administrative cultural influences and that this is why it has had limited success. 


\subsection{Effects of ethnicity on performance appraisal reforms}

The Manyi ani ('I know who') factor seems to have some influence over the way public administration operates in Uganda. Management events in Africa reveal a complex of ethnic 'arithmetic' whereby tribal preferences take precedence over formal procedures for recruitment and promotion (Montgomery 1986). Similar trends were found in the Uganda civil service where respectable leaders indicated that while executing the performance appraisal form, it is the personal, kinship, and informal relations that guide most of the process, though it will not be admitted or documented. In fact one senior bureaucrat has this to say: 'Even when I have a brother or relative in another department, I try to seek friendship with his boss so that he favours him, and this is or will be replicated in my own department if chance arises'.

The impression created therefore is that it is who you know, not what you know that really matters while being evaluated. In doing so, at least five steps in the appraisal process are watered down: a) The agreement on targets is not taken seriously because the evaluation should be based on the agreed-upon targets and not influenced by these relationships. b) The commitment to the appraisal process is undermined because the appraisal system requires that merit is rewarded and failure sanctioned. However, in this case it is ethnicity which is the centre of focus. c) The feed back process is influenced by ethically based appraisal conduct. The feedback will either be biased or based on the wrong premise. d) This also indicates the absence of transparency. If, for example, a rater gives a ratee a poor mark, he will not openly tell the ratee 'I gave you this kind of evaluation on the basis of ethnicity'. In fact, even when a positive evaluation is made, transparency will not be a priority. e) Objectivity is compromised at the expense of ethnicity.

Another widely voiced observation is technical know who, implying that civil servants who have a strong sense of networking make themselves liked and indispensable. To them, the performance appraisal system is not a big deal; in any case, they will be graded well even though they may not be effective.

In order to orient subordinates towards personal task accomplishment, they should be assured that they do not need to have ethnically based support. For instance, the rater - ratee dialogue during feedback sessions should examine how the subordinate can be helped to improve performance but not to favour them as co-ethnic workers or disfavour them because they do not belong to their ethnic group. Relationships in the workplace can also undermine the impact of this particular appraisal system if they are based on ethnicity. The performance appraisal provides for discovering performance problems of fellow civil servants. But the senior officials may find themselves in a situation where they do not want to embarrass the ratee if they share a common ethnicity. As such, they become reluctant to criticize the ratee's performance and shy away from providing honest opinions on the performance appraisal form. Respondents intimate that owing to a common desire for good relationships, a mediocre civil servant has chances of getting a satisfactory grade.

It has been observed that ethnicity impacts most behaviour in multi-ethnic societies (Allen 1994), and when people join organizations, their ethnic commitments and values lie inherent in their identity and are reflected through their work behaviour. Arguably, people in Uganda are group-oriented and paternalistic in nature, and therefore are capable of searching for ethnic homogeneity as an adaptive response to alienation in the work place. Over $75 \%$ of respondents in this study opine that tribal and ethnic considerations influence administrative practices in the civil service. Interviewees divulge that in some public departments people from western and southern Uganda dominate senior posts. Therefore, some individuals do not feel valued because of where they were born, and this affects the way they handle the performance appraisal process. This issue of exclusion has been blamed for causing dissatisfaction, reducing morale, increasing absenteeism and poor motivation in the way the appraisal reforms are perceived and implemented. Those who feel left out on the basis of ethnicity mishandle the performance appraisal through resentment-based resistance, and subtle acts of non-cooperation. They believe this is a justifiable way to 'get even' for perceived mistreatment and a way to exercise their power to mitigate perceived injustice.

In some cases ethnic homogeneity has enhanced the effective and successful implementation of the performance appraisal because people sharing values are likely to support one another during crises, and the lower staff may accept appraisal results from their own 'kin'. This is commonly seen in the recruitment and deployment of support staff. Respondents reveal that it is common for an officer who is entitled to official transport to prefer a driver who hails from the same district. The individual's closest colleagues will also usually share the same ethnic identity, that is, be from the same tribe and speak the same mother tongue. The existence of a complex system of 'ethnic arithmetic', by which tribal preferences take precedence over formal procedures for recruitment and promotion, can be found in governments everywhere. In Africa few managers are prepared to 
deal head-on with such issues, even if it causes morale problems amongst their own staff (Montgomery, 1986, p.22).

Given that the performance appraisal plays a role, albeit a minor one (at least it is considered one criteria for promotion), it follows that individuals may indulge in ethnicity for the sake of having favourable results posted on their performance appraisal records. In fact, a senior civil servant intimated that he himself is aware of some officials in his ministry who have been beneficiaries of such tendencies. He is however quick to add that the practice is neither widespread nor condoned. It is hardly revealed and is therefore an insidious factor in undermining the effective implementation of the performance appraisal.

\section{Conclusion}

I conclude that Ugandan civil servants have been reluctant to embrace the performance appraisal system because it does not 'fit' with the dominant cultural attitudes and administrative behaviour. These deep-seated cultural tendencies of strong uncertainty avoidance and large power distance may be barriers to the NPM led performance appraisal system. But apart from a cultural adjustment programme on the part of the civil servants, reformers must recognize the nature of Uganda's bureaucracy and design a performance appraisal system that does not appear to undermine or confront these cultural tendencies. Instead they must manipulate them and shape a performance management tool for building a culture of performance. It has been observed that though civil servants want to remain politically neutral, they are compelled by their line of work to pay allegiance to the ruling regime. While some seem to deeply distrust the politicians, others receive political patronage. Results indicate that the performance appraisal is sabotaged by the civil servants because they are politically neutral and less partisan. We have also realized that Uganda's civil service is ethnically fractionalized. This has led to irregular appointments and promotions, which definitely undermine the intention of the merit-based appraisal system.

Thus, public sector reformers could design the performance appraisal to pass a cultural compatibility test; it should be consistent with the host administrative cultures and this can be done in two possible ways: a) by carrying out a 'cultural adjustment programme' whereby the civil servants are taken through a process of unlearning certain norms and practices and being indoctrinated and educated with norms and values that may ease the process of the NPM inspired appraisal system; $b$ ) review the performance appraisal system so that it can accommodate and acknowledge the context and thus become sensitive to the host cultural values.

The study suggests future research that might be needed in order to understand better the role of administrative culture on performance appraisal. It may be helpful to carry out a longitudinal study and observe how the appraisal process is conducted in the public service over a long and continuous period. Although administrative culture was the main field of study here, the adoption of other perspectives in order to understand the performance appraisal system represents a valuable area of study to pursue. The study also raises the question of the underlying motives of policy reforms. Future studies should be carried out to investigate further why certain reformers do not treat culture as important.

This study has at least two implications for other African countries: first, administrative culture matters and it should be studied, understood, managed and developed. Secondly, it is important to establish how administrative culture manifests itself in various ways across Africa and influences policy reform and change in each country. This is because most of the reforms, such as the performance appraisal, are structured according to Anglo-Western value systems which are instrumentally rational and hence may not be congruent with the African culture.

I thus contend that in order to carry out a successful performance appraisal reform, it may be useful to a) raise the recognition of culture as a critical factor when introducing performance appraisal, b) weed out obstructive elements in the administrative culture of the Ugandan civil service, and c) promote and reward constructive elements in the administrative culture in order to increase the possibilities for the appraisal reform's success. In sum, as the Ugandan case demonstrates, administrative culture matters for the successful implementation of performance appraisal reforms in Africa.

\section{References}

Allen, S. (1994). The Dynamics of Race and Gender: Some Feminist Interventions. In. H. Ashfer and M. Maynard (Eds.), Race, Ethnicity and Nationality: Some Questions of Identity. London: Taylor and Francis.

Armstrong, M. (1996). A Handbook of Personnel Management Practice (6th ed). London: Kogan Page. 
Aycan, Z. (2005). The interplay between cultural and institutional/structural contingencies in human resource management practices. International Journal of Human Resource Management, 16 (7):1083-119. http://dx.doi.org/10.1080/09585190500143956

Baldersheim, H., Ishtiaq, J. \& Salahuddin, A. (2001). Electoral Participation in Bangladesh:Explaining Regional Variations. Commonwealth and Comparative Studies. 39 (1):51 -72. http://dx.doi.org/10.1080/713999547

Brett, E. (1994). Rebuilding Organisational Capacity in Uganda under the National Resitance Movement. The Journal of Modern African Studies, 32 (1):53-80. http://dx.doi.org/10.1017/S0022278X00012544

Brooks, A.K. \& Tamara, C. (2007). Where to Now? Race and Ethnicity in Workplace Learning and Development Research: 1980-2005. Human Resource Development Quarterly, 18(2):229-51. http://dx.doi.org/10.1002/hrdq.1201

Caiden, G.E. (2006). Public Service Reform. In A. Shafiqul, H. \& Zafarulla, H. (Eds.), International Development Governance. Boca Raton: Taylor and Francis Group.

Chabal, P. \& Daloz, J. (1999). Africa Works: Disorder as Political Instrument. Oxford: James Curry.

Christensen, T., Lægreid, P., Roness, P. \& Røvik, A.K. (2007). Organisation Theory and the Public Sector: Instrument, Culture and Myth. New York: Routledge. http://dx.doi.org/10.4324/9780415449014

Clerk, N. (1990). Report of The Public Service review and Reorganisation Commission 1989/1990. Kampala: Government of Uganda.

Cook, J. \& Crossman, A. (2004). Satisfaction with performance appraisal systems. Journal of Managerial Psychology, 19(5):526-41. http://dx.doi.org/10.1108/02683940410543605

de Jager, P. (2001). Resistance to change: a new view of an old problem. The Futurist, 24-7.

Erdmann, G. \& Engel, U. (2006). Neopatrimonialism Revisited - Beyond a Catch-All Concept. In Program, G. R. (Eds.), Legitimacy and Efficiency of Political Systems. Hamburg GIGA German Institute of Global and Area Studies

Fletcher, C. \& Perry, E. (2001). Performance appraisal and feedback: A consideration of national culture and a review of contemporary research trends. In N. Anderson, D. S. Ones, H. K. Sinangil and C. Viswesvaran (Eds.), Handbook of Industrial, Work and Organizational Psychology, Volume 2: Organizational Psychology. London: Sage.

Groeschl, S. (2003). Cultural implications for the appraisal process. Cross Cultural Management: An International Journal, 10(1):67 -79. http://dx.doi.org/10.1108/13527600310797540

György, H. (2004). The spirit of management reforms: towards building an explanatory model of NPM. A comparative case study of Queensland and Hungarian administrative culture. Budapest University of Economics and Public Administration, Hungary Panel Track: Public Management Reform in Transitional Nations: Eighth International Research Symposium on Public Management.

Hameso, S.Y. (1997). Ethnicity in Africa: Towards a Positive Approach. London. University Press.

Henderson, K.M. (2005). American Administrative Culture. In Jabbra, J. G. \& Dwivedi, O. P. (Eds.), Administrative Culture in a Global Context. Whitby: de Sitter Publications.

Hofstede, G. (1980). Cultures consequences: International Differences in work related values. Beverly Hills: Sage.

(1997). Cultures and Organizations, Software of the Mind. McGraw-Hill.

(2001). Cultures Consequences: Comparing values, behaviours, institutions and organisations across nations. Thousand Oaks: Sage.

Hofstede, G. \& Hofstede, G.J. (2005). Cultures and Organisations: Software of the mind, Intercultural cooperation and its importance for survival. McGraw-Hill.

Horowitrz, D. (1994). Democracy in divided societies. In Diamond, L. \& Plattner, M. (Eds.), Nationalism, Ethnic conflict and Democracy. Baltimore and London: The John Hopkins University Press.

House, R., Hanges, P., Javidan, M., Dorfman, P. \& Gupta. V. (2004). Culture, Leadership and Organisations: The GLOBE Study of 62 Societies. Thousand Oaks.London.New Delhi: Sage Publications.

Hyden, G. (2006). African Politics in Comparative Perspective. Cambridge: Cambirdge University Press. 
Institute, Uganda Management. (2002). Report on Proceedings of a one day Dissemination Workshop for the DESA Public Service Ethics in Africa Project, at The Global Distance Learning Center, UMI, Kampala.

Islam, N. (2004). Sifarish, sychophants, power and collectivism: administrative culture in Pakistan. International Review of Administrative Sciences, 70(2):311-30. http://dx.doi.org/10.1177/0020852304044259

Jabbra, J.G. \& Jabbra, N. (2005). Administrative Culture in the Middle East: The case of the Arab World. In Jabbra, J. G., \& Dwivedi, O.P. (Eds.), Administrative Culture in a Global Context. Whitby: de Sitter.

Jahoda, G. (1984). Do we need a concept of culture? Journal of Cross Cultural Psychology, 15:139-52. http://dx.doi.org/10.1177/0022002184015002003

Jamil, I. (1998). Administrative Culture in public Administration: Five Essays on Bangladesh. Bergen. LOS Senteret

Javidan, Mansour, Robert House \& Peter Dorfman. (2004). A nontechnical Summary of GlOBE findings. In R. House, Hanges, Paul, M. Javidan, P. Dorfman and V. Gupta (Eds.), Culture, Leadership and Organisations: The GLOBE Study of 62 Societies. Thousand Oaks.London.New Delhi:: Sage Publications.

Kagolo, F. (2008). Makerere University Kampala Dons Clash Over Tribalism. The New Vision, May 1.

Karyeija, G. (2010). Performance appraisal in Uganda's civil service. Does administrative culture matter? Unpublished PhD dissertation, University of Bergen

Kiyaga-Nsubuga, J. (2004). Leadership Challanges in mainstreaming Performance Enhancement in the Public Service. Paper read at Public Sector Leadership Capacity Development for Good Governance in Africa, at Kampala, Uganda.

Kraiger, K. \& Ford, J. K. (1985). A meta-analysis of ratee race effects in performance ratings. Journal of Applied Psychology, 70:56-65. http://dx.doi.org/10.1037/0021-9010.70.1.56

Lentz, C. (1995). 'Tribalism' and ethnicity in Africa: A review of four decades of anglophone research. Cah.Sci.hum, 31(2):303-28.

Luvuno, L.L. (2005). Reconstructing South African Administrative Culture. In Jabbra, J. G. \& Dwivedi, O. P. (Eds.), Administrative Culture in a Global Context. Whitby: de Sitter Publications.

Mamdani, M. (1996). Citizen and subject: contemporary Africa and the legacy of colonialism. Princeton: Princeton University Press.

McCourt, W. \& Foon, L.M. (2007). Malaysia as model: Policy transferability in an Asian country. Public Management Review, 9(2). http://dx.doi.org/10.1080/14719030701340358

Mcfarlin, D. \& Sweeney. P.D. (2001). Cross-cultural applications of organisational justice. Justice in the Workplace: From Theory To Practice.

McSweeney, B. (2002a). The Essentials of Scholarship:A reply to Hofstede. Human Relations, 55(11):1363 -72.

-------. (2002b). Hofstede's Model of National Cultural Differences and their Consequences: A Triumph of Faith -a failure of analysis. Human Relations, 55:89 -118.

Mendonca, M. \& Kanungo, R.N. (1996). Impact of culture on performance management in developing countries. Performance management, 17 (4/5).

Mitala, J. (2006). Presentation on performance management and governance. Bander Setri Begawan, Brunei Darusalaam: seminar on modernising the civil service in alignment with national goals, 13 -17 November.

Montgomery, J.D. (1986). Level of managerial leadership in southern Africa. The Journal of Developing Areas, 21:15-30.

MOPS, Ministry of Public Service. (2007). Staff performance appraisal in the public service: Guidelines for managers and staff. Government of Uganda.

Mount, M.K., Sytsma, M.R., Hazucha, J.F. \& Holt, K. (2006). RATER-RATEE RACE EFFECTS IN DEVELOPMENTAL PERFORMANCE RATINGS OF MANAGERS. Journal of Personnel Psychology, 50(1):51 -69.

Mount, M. (1984). Satisfaction with a Performance Appraisal Systsem and Appraisal Discussion. Journal of Occupational Behaviour, 5 (4):271 -9. http://dx.doi.org/10.1002/job.4030050404 
Munene, J.C, Schwartz, S.H. \& Smith, P. (2000). Development in subsaharan africa: Cultural influences and managers' Decision Behaviour. Public Administration and Development, 20:339-51. http://dx.doi.org/10.1002/1099-162X(200010)20:4<339::AID-PAD139>3.0.CO;2-\#

Mwenda, A. M. \& Tangri, R. (2005). Patronage politics, donor reforms, and regime consolidation in Uganda. African Affairs, 416: 449-67. http://dx.doi.org/10.1093/afraf/adi030

Mwenda, A. (2007). Personalising Power in Uganda. Journal of democracy, 18(3):33-7. http://dx.doi.org/10.1353/jod.2007.0048

Nef, J. (2005). The Cultuire of Distruct in Latin American public Administration. In Jabbra, J. G. \& Dwivedi, O. P. (Eds.), Administrative Culture in a Global Context. Whitby: de Sitter Publications.

Nnoli, O. (1993). Ethnicity. In Krieger, J. (Ed.), The Oxford Companion to the World of politics. Oxford: Oxford University Press.

Okuku, J. (2002). Ethnicity, State Power and the Democratistion Process in Uganda. Uppsala.

Olivier de Sardan, J. P. (1999). A Moral economy of corruption in Africa. The Journal of Modern African Studies, 37(1):25-52. http://dx.doi.org/10.1017/S0022278X99002992

Peters, G.B. (1999). Institutional Theory and Administrative reform. In Egeberg, M. \& Lægreid, P. (Eds.), In Organising Political Institutions: Essays for Johan P. Olsen. Oslo.: Scandinavian University Press.

Polidano, C. (1999). The New Public Management in Developing Countries. IDPM Public Policy and management Working Paper. Manchester: University of Manchester.

Riggs, F. W. (1964). Administration in Developing Countries: The theory of prismatic society. Boston: Houghton Mifflin.

Schein, E.H. (1999). Process Consultation Revisted: Building the helping relationship. Addison Wesley O.D.Series.

Schick, A. (1998). Why Most Developing Countries Should Not Try New Zealand Reforms. Research Observer, 13(1):123 -31.

Tambiah, S.J. (1989). Ethnic Conflict in the World Today. American Ethnologist, 16(2):335-49. http://dx.doi.org/10.1525/ae.1989.16.2.02a00090

Tayeb, M. H. (1988). Organizations and national culture: a comparative analysis. London: Sage.

Tidemand, P. \& Ssewankambo, E. (2008). Advisory Services for Independent Review of the Uganda Public Service Reform Programme (PSRP). Kampala: MOPS, Ministry of Public Service, Uganda.

Turya-Muhika, S. (1982). Report of the Public Service Salaries Review Commission. Kampala: Government of Uganda.

Wescott, C. (1999). Guiding Principles on Civil service reform in Africa: An Empirical Review. International Journal of Public Sector Management, 12(2-3).

Zhuplev, A. \& Vladamir, I.S. (2005). Administrative Culture in a Borderless World: Russia. In Jabbra, J. G. \& Dwivedi, O. P. (Eds.), Administrative Culture in a Global Context. Whitby: de Sitter Publications.

\section{Notes}

Note 1 . The boss conceives self as a colonial chief who had legislative, executive, judicial, and administrative powers.

Note 2. Informality denotes socially shared unwritten rules that are created, communicated and enforced unofficially.

Note 3. Characteristics of ethnicity are; a) common geographic origin: b) migratory status; c) race; d) language or dialect; e) religious faith; f) ties that transcend kinship, neighborhood, and community boundaries; h) literature, folklore, and music; i) food preferences; j)settlement and employment patterns; $k$ ) special interests in regard to politics; 1) institutions that specifically secure and maintain the group; $m$ ) an internal sense of distinctiveness, and $\mathrm{n}$ ) an external perception of distinctiveness (Thernstrom 1980). 